\title{
PROCEEDINGS OF THE ENTOMOLOGICAL SOCIETY OF AMERICA.
}

\section{New York Meeting.}

The Eleventh Annual Meeting of the Entomological Society of America was called to order by First Vice-President E. P. Felt, in Room 411 of Teachers' College, Columbia University, New York City, at 2 P. M., December 26, 1916. After alluding to the death of the Society's President, F. M. Webster, which occurred on January 3, 1916, Dr. Felt appointed the usual committees, as follows:

Auditing-C. W. Johnson, Wm. A. Riley.

Resolutions-P. P. Calvert, Jas. S. Hine.

Nominations-Henry Skinner, A. P. Morse, J. C. BRADLEY.

The following papers were then read:

Life-histories and Habits of Gerridæ....... J. R. de LA Torre Bueno Notes on the Habits and Immature Stages of Cyrtidæ... J. L. KING Distribution of the Ohio Broods of Periodical Cicada with Reference

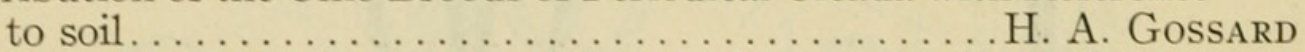
Insect Collecting in Cameroon, West Africa........ Rev. A. I. Good Recent Observations and Theories Concerning the Origin of Social

Habits among Vespidæ.................. Dr. J. Becquaert The Phyletic Value of Ontogenetic Characters in the Elateridæ,

Biological Notes on Miris dolobrata J. A. Hyslop The Malpighian Vessels of the Alder Flea-beetle,

William Colcord Woods

At 5:15 the Society adjourned until the next morning, about 90 members having been in attendance.

December 27, 1916. The morning session was called to order at $9: 30$ by A. P. Morse, in the temporary absence of the First Vice-President. The following papers were read:

Some Recent Advances in Mosquito Work in New Jersey,

Thos. J. Headlee Studies on Coccobacillus acridiorum d'Herelle, and on Certain

Intestinal Organisms of Locusts,

E. Melville du Porte and J. Vanderleck Studies of Hypoderma lineatum and bovis...... Seymour Hadwen 
The time having arrived for the annual business session, the Executive Committee presented the reports of the Secretary, the Treasurer, the Managing Editor of the AnNals, and of the Thomas Say Foundation, as follows:

\section{REPORT OF THE SECRETARY.}

The following members have been elected since the last annual meeting:

On July 17, 1916:

Frederick McMahon Gaige

Walter Allen Price
Shirley Lowell Mason

Lewis G. Gentner

On August 20, 1916:

Gonzalo Martinez Fortun Ernest Melville Du Porte

Walter Norton Hess

Emerson Liscum Diven
H. B. Parks

Maurice E. Hays

C. W. Collins

Ray T. Webber

Chester Ittner Bliss

Rudolf William Glaser

Albert I. Good

Howard L. Clark

Frank R. Cole

Ralph Robinson Parker

Dettmar Wentworth Jones

Edward Riley King

Everett Elmer Wehr

The following members have resigned:

H. H. Brehme

Geo. Franck

The following have died:

Francis Marion Webster, President

A. J. Cook

J. B. Williams

On December 26, 1916:

Paul Hugo Isidor Kahl

Kirby Lee Cockerham

W. B. Williams

Seymour Hadwen

Herbert B. Hungerford

Christian E. Olsen

Phares H. Hertzog

William Bernard Donohue

Wallace Larkin Chandler

George Felix Arnold

Max Kisliuk

J. A. Corcoran

Total, 33.

W. A. Hooker

R. N. Wilson

Total, 4.

Ignaz Matausch

R. M. Moore

Total, 5.

Dropped for non-payment of dues, 11 members. Net gain, 14 .

No Fellows or Honorary Fellows were elected in the year.

On December 14, 1916, the total membership of the Society was 578. Some idea of the interest of the members may be gained from the following figures regarding the payment of dues.

Disregarding for the moment the foreign members, life members, and honorary fellows, there were 10 members who were paid in advance at least for 1917; 414 were paid up for 1916; 54 were paid up for 1915; while 37 were owing for more than two years. These last are liable to suspension, but it costs the Society nothing to carry them, as they do not receive the AnNaLs while in arrears, and the Secretary is endeavoring to revive their interest.

The year just closing has been a trying one for many of our foreign members, and yet their interest has been manifested in a gratifying manner. Out of 54 classed as foreign members (and in this classification the Secretary has rather arbitrarily included Cuba, Porto Rico, and Hawaii with continental North America, and not as foreign territory), the number who have paid dues during the year is just one-half, or 27. Several of these are in the war, and one sent his communication from the trenches. Regarding the other foreign members, obvi- 
ously our wisest policy is to continue to carry them on the books until peace returns and they have an opportunity to resume the payment of dues. We all hope that they will then rejoin us in active membership.

The membership on December 14, 1916, was in the following classes:

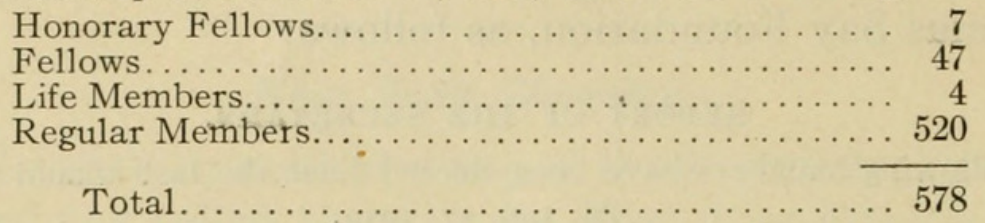

Add 33 new members just voted in and our present membership is raised to 611 .

\section{TREASURER'S REPORT.}

\section{RECEIVED:}

Balance last Treasurer's Report (Annals, March, 1916, p. 108) $\$ 110.36$, less $\$ 12$ outstanding check for clerical work for

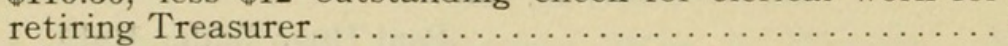

Dues from members................................ 930.44

$\begin{array}{lr}\text { From Herbert Osborn, Managing Editor... } \ldots \ldots 1 y, 1916 \ldots \ldots \ldots \ldots & 10.29\end{array}$

Interest on current balance.......................... 3.88

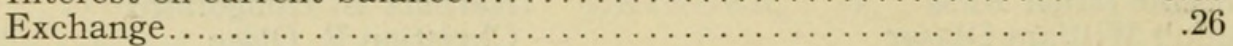

Total

$\$ 1,397.56$

\section{PaId Out:}

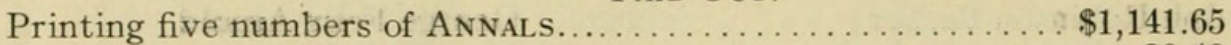

Engraving for ANNALs........................ 30.40

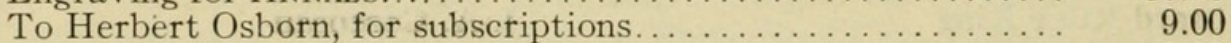

Refunded to N. K. Jardine......................... 3.33

Thomas Say Foundation, preliminary expenses.............. $\quad 40.00$

Printing for Secretary's office......................... 30.00

Stamped envelopes............................... 39.08

Clerical assistance............................. 41.00

Badges for annual meeting . . . . . . . . . . . . . . . . . . . 11.00

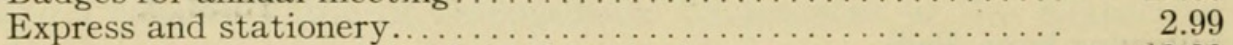

Interest on permanent funds, redeposited................. 10.29

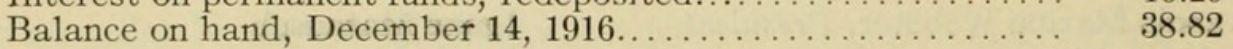

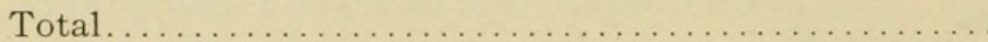

Condition of Permanent Funds.

On deposit in Cleveland Trust Co., January .1, 1916:

Four life memberships . . . . . . . . . . . . . . . . . . . . . . \$200.00

Samuel Hubbard Scudder Fund... . . . . . . . . . . . . . . . . 35.00

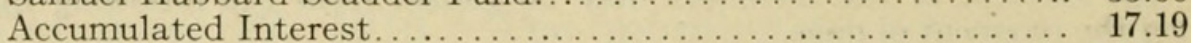

Total.

Interest added to deposit:

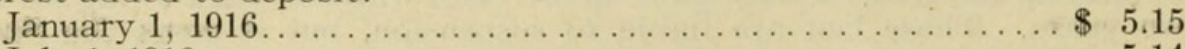

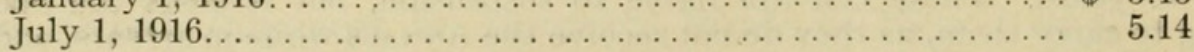

Total. ............................. 10.29

Total on Deposit December $14,1916 \ldots \ldots \ldots \ldots \ldots \ldots \ldots \ldots \ldots \ldots \ldots \ldots \ldots \ldots \ldots$

In accordance with previous action of the Executive Committee, enough of the accumulated interest will be added to the Samuel Hubbard Scudder Fund to bring it up to Fifty Dollars; this leaves the remainder of the interest, which may be drawn for running expenses of the Society, at \$12.48. 


\section{REPORT OF THE MANAGING EDITOR OF THE ANNALS OF THE ENTOMO-} LOGICAL SOCIETY OF AMERICA.

It has been possible during the present year to slightly increase the size of the volume as compared with the preceding year and the income which seems to be assured for the coming year will enable us to maintain the Jou RNAL on the present basis.

The receipts and expenditures may be summarized as follows:

\section{RECEIPTS.}

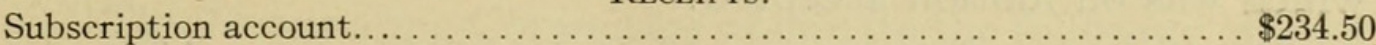

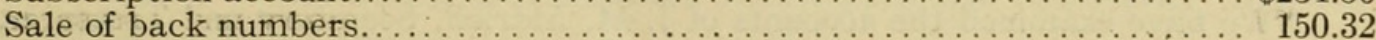

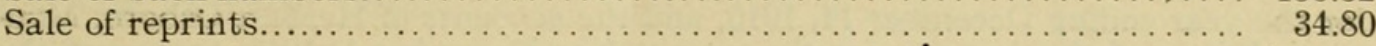

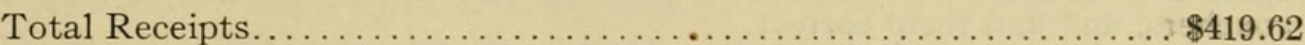

DisBuRsements.

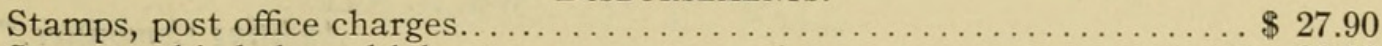

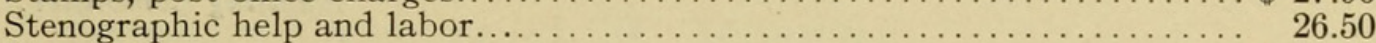

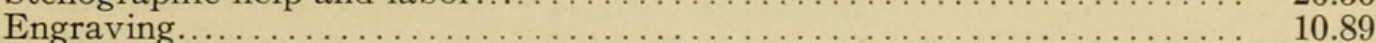

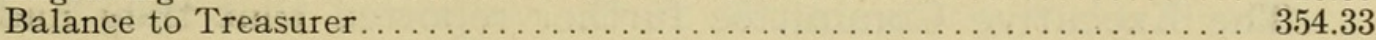

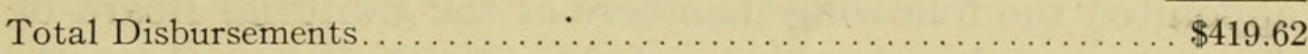

The appeal made to the members in regard to filling out their back sets seems to have been effective in a number of cases, as a larger number of back numbers were sold during the past year than in either of the two preceding years. We desire to express our appreciation for this assistance and especially for the securing of Library subscriptions which are ordinarily to be considered as continuations which will be of advantage to the publication in the future.

Respectfully submitted,

Herbert Osborn, Managing Editor.

\section{REPORT OF THE THOMAS SAY FOUNDATION.}

Of the six members of the Foundation appointed at the last annual meeting, Dr. Calvert resigned, and the Executive Committee by mail ballot, appointed J. M. Aldrich as editor, leaving the Foundation temporarily with only five members.

A meeting of the Foundation was called and convened at West LaFayette, Indiana, on September 11 and 12, 1916, at which were present A. D. MacGillivray, E. B. Williamson and J. M. Aldrich, a majority of the members. At this meeting J. M. Aldrich proposed that the Foundation print as its first volume his completed manuscript on "Sarcophaga and Allies in North America." On calculating the probable expense, the members believed that they were justified in going forward, and accepted the work as the first volume of the Foundation. Specifications were drawn up and bids obtained, and a contract let to the Murphey-Bivins Co., LaFayette, Indiana.

Arrangements were also made for the circulation of another appeal for tendollar advance subscriptions in the same envelope with the announcement of the coming meeting of the Entomological Society of America.

After the meeting, the printing of the book was completed according to contract, and subscribers have already received their copies.

A balance of $\$ 40.88$ in the appropriation for preliminary expenses (ANNALs, March, 1916, p. 112) was drawn upon as follows:

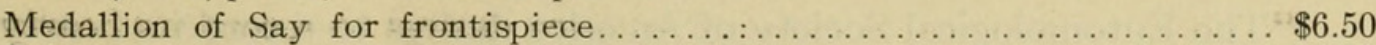

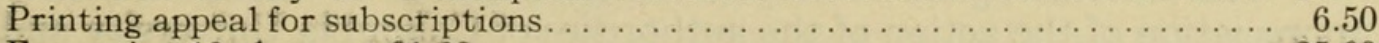

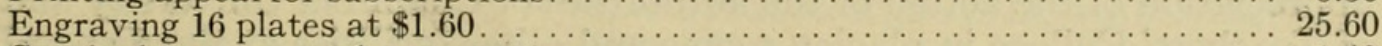

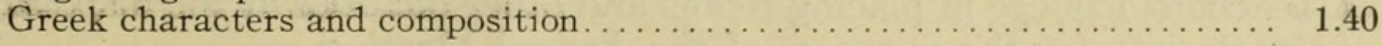

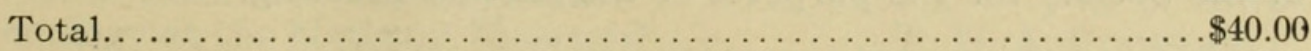


The cost of printing an edition of 1000 and binding 200 is in all $\$ 456.00$ in addition to the items mentioned above. This amount is due January 1. At the time of writing the funds in hand are somewhat over $\$ 300$; the balance is arranged for temporarily, but will soon be made up from sales.

Respectfully submitted,

J. M. ALDRICH, Editor.

The Auditing Committee submitted the following report, which was on motion accepted:

"We have examined the accounts of J. M. Aldrich, Secretary and Treasurer, for the year ending December 14, 1916, and the accounts of Herbert Osborn, Managing Editor of the AnNaLs, for the year ending December 1, 1916, compared the vouchers, and find them correct.

(Signed) Chas. W. Johnson, WM. A. Riley,

Auditing Committee."

The Executive Committee further reported that they had appointed the following members of the Editorial Board of the AnNals to take the place of Messrs. Kellogg, Howard and Wheeler, whose terms have expired:

T. D. A. Cockerell, Wm. A. Riley, L. O. Howard.

Also that they had appointed the following members on the Thomas Say Foundation, in pursuance of the Constitutional provisions adopted since the last appointments a year ago:

Members for two years-Nathan Banks, A. D. MaCGillivray.

Members for one year-Morgan Hebard, E. B.Williamson.

Editor-J. M. ALDRICH.

Treasurer-E. D. BALL.

The Committee further reported, in the case of a certain member whose commercial efforts were open to criticism, and were apparently aided by his advertising himself as a member of this Society, that the Secretary is instructed to request him to resign; if he does not do so, the Secretary is instructed to drop his name from the books and publish a statement of the facts in the ANNALS.

The Committee on Resolutions submitted the following report, which was on motion adopted:

"The Entomological Society of America desires to record its hearty appreciation of the action of the authorities of Columbia University and of 'Teachers' College in placing rooms and other facilities at the disposal of the Society for the purposes of the Annual Meeting. 
The Society also thankfully acknowledges the courtesies it has received and is about to experience this evening from the American Museum of Natural History and from the Entomological Societies of New York and Brooklyn.

(Signed) Philip P. Calvert, JAS. S. Hine,

Committee:"

The Nominating Committee submitted the following report:

"The Nominating Committee nominate the following officers for the coming year:

President-Lawrence Bruner.

First Vice-President-E. M. Walker.

Second Vice-President-H. C. FALL.

Secretary-Treasurer-J. M. ALDRICH.

Executive Committee-E. B. Williamson, A. D. Hopkins, W. J. Holland, E. D. Ball, C. W. Johnson.

Respectfully submitted,

(Signed), Henry Skinner,

A. P. Morse,

J. Chester Bradley,

Committee."

On motion, the Secretary was instructed to cast the ballot of the Society for the officers; which being done, they were duly declared elected.

Dr. Skinner moved that in the opinion of the Society, in taxonomic work a single type should be used, and that we recommend this policy. The motion being seconded, Professor Riley moved to refer it to the Committee on Nomenclature with instructions to report, which was carried.

Professor Riley moved that it be the sense of the meeting that papers should be limited to ten minutes. Dr. Headlee moved to leave the matter to the Secretary, which was carried.

No further business appearing, at $12 \mathrm{~m}$. the Society adjourned until afternoon.

December 27, 1916, 2 P. м. The Society was called to order by Vice-President Felt, and the program of papers was continued, as follows:

Some Modifications in the Legs of Insects,

A. Peterson and A. D. MacGillivray The Morphology of a Lepidopterous Head ............ Edna Mosher The Genus Erax in North America ................ JAs. S. Hine Entomology at the National Museum*......... T. D. A. Cockerell

* Published in Entomological News, xxviii, p. 55, Feb., 1917. 
Following Professor Cockerell's paper, it was moved and carried that a committee be appointed by the Executive Committee to promote the adequate development of the insect collections of the National Museum. Vice-President Felt stated that the committee would be announced at the evening session. The reading of papers continued, as follows:

Entomological Charts....................... P. Metcalf A Guide to a Laboratory Study of the Scale Insects.... R. A. Cooley The Food of Drosophila..................... J. P. BAumberger Observations on Grylloblatta campodeiformis..... C. GoRdon HewitT Sarcophaga haemorrhoidalis Larvæ as Parasites of the Human

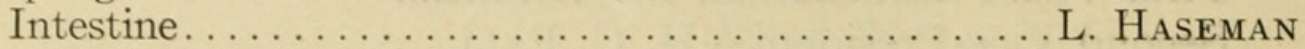

(On account of the absence of the authors, the last two were read by the Vice-President and the Secretary.)

At 5:10 P. M., the Society adjourned until evening.

At 6 P. M., in company with the Association of Economic Entomologists, in the rooms of the American Museum of Natural History, the society was entertained by the New York and Brooklyn Entomological Societies at a buffet supper; and at $7: 30 \mathrm{P}$. M. reassembled in one of the lecture rooms of the Museum, where the Annual Address of the Entomological Society of America was delivered by Professor T. D. A. Cockerell, on the subject, "Fossil Insects."

On calling the meeting to order, Vice-President Felt announced that the Executive Committee had selected the following committee to promote the adequate development of the insect collections of the National Museum:

T. D. A. Cockerell, Herbert Osborn, H. T. Fernald, Wm. M. Wheeler, Jas. G. Needham.

The program of the Annual Meeting having been completed, the Society adjourned sine die.

(Signed) J. M. Aldrich, Secretary-Treasurer.

\section{NOTICE.}

In accordance with instructions given me by the Executive Committee at the Annual Meeting in New York City, on December 27, 1916, I have dropped the name of James Sinciair from the list of members of the Entomological Society of America.

\section{J. M. Aldrich, Secretary-Treasurer.}

West Lafayette, Ind., Feb. 9, 1917. 


\section{$2 \mathrm{BHL}$ Biodiversity Heritage Library}

Aldrich, John Merton. 1917. "New York Meeting." Annals of the Entomological Society of America 10, 98-104. https://doi.org/10.1093/aesa/10.1.98.

View This Item Online: https://www.biodiversitylibrary.org/item/43648

DOI: https://doi.org/10.1093/aesa/10.1.98

Permalink: https://www.biodiversitylibrary.org/partpdf/193656

\section{Holding Institution}

Smithsonian Libraries

\section{Sponsored by}

Smithsonian

\section{Copyright \& Reuse}

Copyright Status: NOT_IN_COPYRIGHT

This document was created from content at the Biodiversity Heritage Library, the world's largest open access digital library for biodiversity literature and archives. Visit BHL at https://www.biodiversitylibrary.org. 